\title{
FERRAMENTA: O HOMEM ${ }^{* 1}$
}

Mauro Pereira ${ }^{2}$

\section{JOGO DE ESPELHOS}

O sentido

Do homem

É efêmero.

Esconde vozes

Mortas.

Esconde braços

Frouxos.

É um espelho

Dentro de

Outro espelho

Múltiplo.

1 Poemas selecionados de Antologia não publicada.

${ }^{2}$ Filosofia - FFLCH - USP. 


\section{MEU ESTRANHO CORPO}

Estranho é o meu corpo

Assim desnudo

Mostrando mutilações

De que me queixo.

Orgânico é pouco

Para defini-lo.

Opaco é vago. Mas

Se dissesse ordenado

Talvez definisse sua

Quase nua totalidade:

Estes pés, estas mãos

Este sexo de aspecto engraçado.

Estranho é o meu corpo

Este lado cru que habito

E padeço. 


\section{DAQUI EU OUÇO}

Daqui eu ouço

$\mathrm{O}$ arrastar do vento.

Bate o portão

Encosta a porta

Empurra o tempo.

Estou sem voz

Para avisar o mundo

Enviar consolo e ternura

Para quem deseja.

Daqui eu ouço

E me calo tão grande

É minha covardia. 


\section{NÃO LAMENTO}

Não lamento, apenas penso.

Se o que transfigura é o exato

Então as linhas são proporções

De outros corpos equivocados

Surgindo destes que agora vejo.

Se o que transfigura é o efeito

Os fenômenos ligados a nós

São meras estações enfeitadas

Onde partidas não ditam regras

Nem exatas ou meias proporções.

Não lamento. Sei o que sou.

Exemplo inacabado de uma frase

Escrita e usada como fogo

Em extrema reverência. 